\title{
Effect of Varied Soil Moisture Content on Seed Yield of Six Range Grasses in the Rangelands of Kenya
}

\author{
Koech O. K. ${ }^{1, *}$, Kinuthia R. N. ${ }^{1}$, Mureithi S. M. ${ }^{1}$, Karuku G.N. ${ }^{1}$, Wanjogu R.K. ${ }^{2}$ \\ ${ }^{1}$ University of Nairobi, Department of Land Resource Management and Agricultural Technology, Kenya \\ P.O Box 209053-00625, Nairobi \\ ${ }^{2}$ National Irrigation board, Mwea Irrigation Agricultural Development (MIAD) Centre P O Box 210, 10303, Wanguru, Kenya \\ *Corresponding Author: okkoech@yahoo.com
}

Copyright (C) 2014 Horizon Research Publishing All rights reserved

\begin{abstract}
Seed yields of six range grass species grown at 80,50 and $30 \%$ field capacity (FC) soil moisture content and rain fed condition were evaluated. The grasses included Chloris roxburghiana, Eragrostis superba, Enteropogon macrostachyus, Cenchrus ciliaris, Chloris gayana and Sorghum sudanense (Sudan grass). Watered treatments had higher seed yields compared to rain fed for all the grasses. Chloris roxburghiana had higher seed yields at 50 and $30 \%$ FC (516.1 and $633.4 \mathrm{~kg} \mathrm{ha}^{-1}$, respectively), and lower yields at $80 \% \mathrm{FC}$ and rain fed treatment (103 and $54.3 \mathrm{~kg} \mathrm{ha}^{-1}$, respectively). Eragrostis superba and Enteropogon macrostachyus showed no difference in seed yields across watered. Cenchrus ciliaris had no significant difference among watered and rain fed. Chloris gayana produced higher seed yields at $30 \% \mathrm{FC}\left(1066.8 \mathrm{~kg} \mathrm{ha}^{-1}\right)$ while 80 and $50 \% \mathrm{FC}$ and rain fed having 766.9, 866.8 and $123.7 \mathrm{~kg} \mathrm{ha}^{-1}$, respectively. The highest yield was observed in Sorghum sudanense at $80 \% \mathrm{FC}$ and was different $(\mathrm{p} \leq 0.05)$ from the others $\left(1250 \mathrm{~kg} \mathrm{ha}^{-1}\right)$, with $50,30 \% \mathrm{FC}$ and rain fed having 700.5 , 533.9 and $150.7 \mathrm{~kg} \mathrm{ha}^{-1}$, respectively. Sorghum sudanense was highest yielder under rain fed $\left(150.7 \mathrm{~kg} \mathrm{ha}^{-1}\right)$ with least being Cenchrus ciliaris $\left(21.8 \mathrm{~kg} \mathrm{ha}^{-1}\right)$. Chloris gayana and Sorghum sudanense have demonstrated potential higher seed yielders under lower moisture supply.
\end{abstract}

Keywords Field Capacity, Irrigated Pasture, Range Grasses, Grass Seeds, Soil moisture content, Kenya

\section{Introduction}

The Kenyan rangelands have become less productive in terms of livestock forage due to range degradation [10], [22]. This has become more severe with the increasing climate change phenomenon that has resulted into reduced precipitations leading to reduced livestock productivity due to feed shortage [20]. The main drivers of rangeland degradation are related to overgrazing, inappropriate cultivation in the marginal and fragile areas, deforestation and climate change $[5,18]$ hence accelerated loss of dryland community's livelihoods in the long term. The effects of land degradation has far much impacts on livestock production [21,30] with direct effects on reduced feed supply, reduced carrying capacity and the frequently observed livestock mortality due to starvation.

Production of pastures under irrigation for dry season use has been used as one of the interventions for sustaining and improving forage production and consequently improving livestock production in Kenyan rangelands [16, 18, 19]. Integration of crops, pastures and livestock production has shown some benefits in pastoral areas especially under irrigation conditions $[2,3]$ have argued that dryland ecosystems are more sustainable than has previously been accepted, as long as livestock, crops and pastures are integrated to complement each other. Establishment of irrigated pastures has been touted as one of the ways to enhance adaptation of livestock production to climate change in the drylands through utilization of established pastures for strategic feeding during dry seasons [36]. This is especially so because pasture production under natural rainfall has failed to sustain the pastoral production systems. Past studies on performance of range grasses under irrigation have shown greater potential in Kenyan rangelands $[18,24,25,26]$. However, these studies looked at range grass biomass productivity and ecological restoration and never evaluated the productivity at different soil moisture content as an indication of water use efficiency. The increasing pressure on available water use for both crops as well as pastures calls for studies that maximize on water available with greater benefits in biomass and seed yields.

There has been increasing demand of range grass seeds for rehabilitation of degraded rangelands of Kenya and establishment of irrigated native pastures; however, the challenge has always been access to adequate quantities of seeds of better quality $[17,27]$. Many efforts to reclaim denuded rangelands have always shown some positive response, for example range land reseeding in Kenya by charitable trust organization; "Reclamation of Arid 
Environments (RAE)", has reclaimed denuded areas of Baringo County using range grasses under rainfall conditions. Other efforts have been done in the southern rangelands of Kenya with the support of Kenya Agricultural Research Institute (KARI). However, the impacts and areal coverage are far less from benefitting the vast degraded rangelands. This is due to low seed yields from multiplication practices under rainfed, which has also been unreliable from the prevailing seasonality and highly variable climatic conditions. This calls for more research on grass seeds multiplication for rehabilitation and pasture establishment for improved livestock production. Study by [18] reported farmer's efforts to rehabilitate denuded southern rangelands to be affected by lack of adequate seeds, poor quality seeds and many efforts by farmers do not show sustainability of their interventions.

This study aimed at evaluating the potential of six grass species for seed production under irrigation at different soil moisture content. Most studies have been focusing on evaluating the impacts of agronomic management on grass seed yields with little attention to water management techniques and its effects on seed production [4, 6, 7]. This study contributes to information on varied soil moisture content effects on range grass seed yields which could be useful in large scale seed multiplication for reseeding, as well as providing farmers with access to grass seeds for pasture production. This is further supported by the current increasing demand for rangeland rehabilitation, increasing livestock forage demand, making grass seed production a priority for Kenyan rangelands[16, 18, 19].

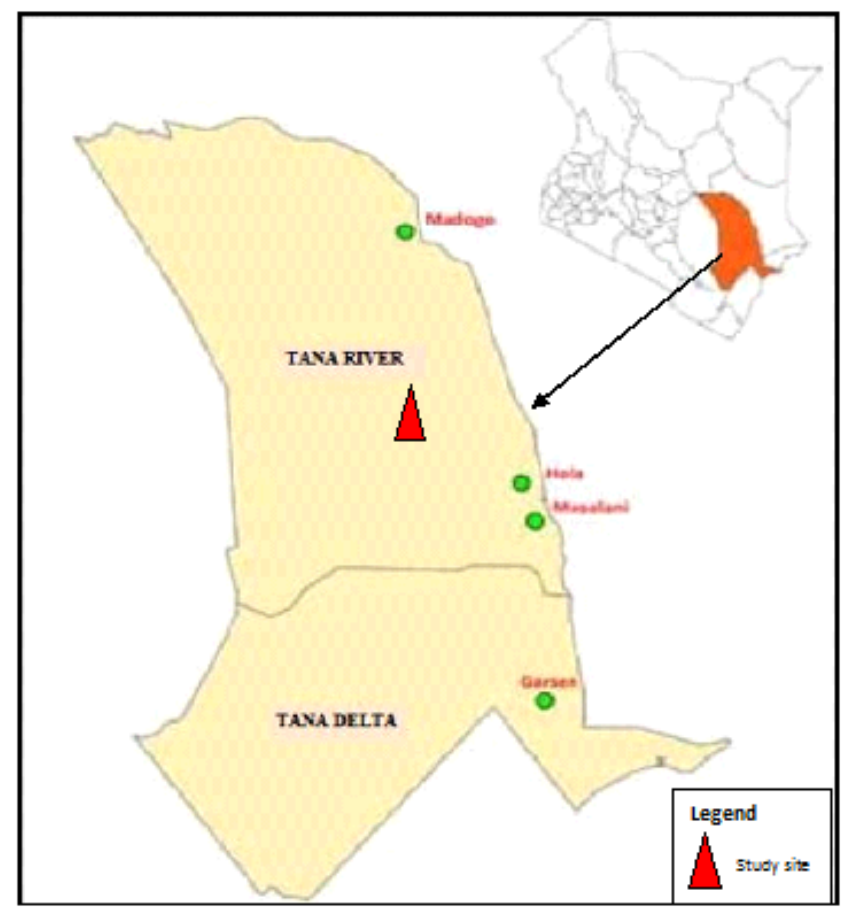

Figure 1. Study area and site map

\section{Materials and Methods}

\subsection{Study Area}

The study was carried out is in Tana River County (figure 1 ), within coordinates $1^{\circ} 30^{\prime} \mathrm{S}, 40^{\circ} 0^{\prime} \mathrm{E}, 1.5^{\circ} \mathrm{S} 40^{\circ} \mathrm{E}$. The climate of the area is hot and dry with daily temperatures ranging between 20 and $38^{\circ} \mathrm{C}$. Rainfall is bimodal in distribution with long rains occurring in April-June and short rains in November-December. Long-term average rainfall ranges from 220 to $500 \mathrm{~mm}$ and is erratic in distribution. Temperatures are highest between February and April and September to October. The County is divided into three livelihood zones; namely, pastoral, agro-pastoral (mixed farming) and marginal mixed farming.

The soil types are vertisols and vertic fluvisols associated with swelling and forming ponds during wet seasons with low infiltration rates from the sealing by high clay content. During dry seasons, the soil dry out and form cracks. At the hinterlands are shallow and have undergone seasons of trampling by livestock, thus are easily eroded during rainy seasons.

Pastoralism and agropastoralism are the main economic activities in the study area, with two established National irrigation schemes, Hola and Bura, with the latter being the experimental study site.

\subsection{Experimental Layout and Design}

One-acre parcel of land that had not been cultivated during the last season was identified within Bura irrigation scheme, National Irrigation Board (NIB) research site. The land was cleared of all bushes, ploughed and harrowed to a fine tilth. The area was then divided into 4 main plots of 39 $\mathrm{m} \times 11 \mathrm{~m}$ size each. The plots within the one acre were demarcated to be 5 metres apart to minimize lateral seepage among main plots. Each main plot was then sub-divided into 30 sub-plots measuring $3 \mathrm{~m} \times 3 \mathrm{~m}$ with $1 \mathrm{~m}$ boundary.

The experimental design was factorial experiments in a completely randomised design comprising two factors, grass species and soil moisture content at 6 and 4 levels, respectively. Main plots demarcated were each randomly assigned a watering schedule as first treatment where treatment one $\left(\mathrm{T}_{1}\right)$ was $80 \% \mathrm{FC}$, treatment two $\left(\mathrm{T}_{2}\right)$ was $50 \% \mathrm{FC}$, treatment three $\left(\mathrm{T}_{3}\right)$ was $30 \% \mathrm{FC}$ and treatment four $\left(\mathrm{T}_{4}\right)$ was the control (rain fed). The second treatment level was grass species randomly assigned to the 30 sub-plots within each of the 4 main plots in pure and mixed stands. The grass species treatments were; Chloris roxiburghiana - CR, Eragrostis superba- ES, Enteropogon macrostachyus -EM, Cenchrus ciliaris -CC, Chloris gayana -CG, Sorghum sudanense -SB. The species were randomly allocated to the sub-plots.

\subsection{Experimental Materials, Sowing and Irrigation}

Gypsum blocks (GBs) were used to determine different soil moisture content levels. GBs were installed at the centre of each sub plot, at two depths, 15 and $30 \mathrm{~cm}$ in 
separate holes which were dug using a $50 \mathrm{~mm}$ soil auger. Prior to installation they were soaked overnight as recommended. Before installation, moisture readings corresponding to $80 \%, 50 \%$, and $30 \% \mathrm{FC}$ soil moisture content was calibrated for all the GBs using moisture meter which aided in determining prescribed soil moisture content for the main blocks. After installation, wire ends originating from the installed blocks were carefully supported by vertical sticks for ease of taking readings and identification of installation points.

The source of grass seeds was Kenya Agricultural Research Institute (KARI), Kiboko Range Research Station. Before planting, the seeds were tested for germination percentage using the standard seed test by germination method as described by ISTA (1976) before planting. The germination rates obtained were used to determine the mixing and sowing rates of the species. Sowing was done manually in the finely prepared seedbeds. Phosphate fertilizer was applied to all the treatments at the recommended rate of $200 \mathrm{~kg} \mathrm{ha}^{-1}$ to enhance establishment. Thereafter, no fertilizer application was done for the whole data collection period. All other routine pasture husbandry practices such as weeding were done for all the treatments. For each treatment, soil moisture was maintained at the prescribed level through irrigation at the prescribed soil moisture content by means of the Delmhorst Soil Moisture Meter Gypsum Blocks (GBs) installed within each sub-plots.

\subsection{Seed Yields Determination}

A seed yield were determined by hand harvesting of mature and ripened seeds from an area of $1 \mathrm{~m} \mathrm{x} 1 \mathrm{~m}$ using quadrat and was replicated three times on each sub-plots. This was done at the time of full maturity and ripened seeds. The seeds were stored in labelled brown paper bags, oven dried at $60^{\circ} \mathrm{C}$ for 48 hours, and weights taken using a digital balance which were later converted into yields per hectare.

\subsection{Data Analysis}

Data collected was subjected to Analysis of Variance (ANOVA) using SAS Version 9 [28] to determine the significance of the treatment effects of varied soil moisture content on productivity of the different grass species. Where significant difference was detected, the means were separated by least significant difference (LSD) at 5\% probability level.

\section{Results}

Seed yields of the six range grasses are presented in Table 1. There was significant difference $(p \leq 0.05)$ in seed yields for the different species at all the three soil moisture content levels and rainfed. Chloris roxburghiana showed significant differences $(p \leq 0.05)$ in yields across the 80,50 , $30 \%$ FC soil moisture content and rain fed having 103.3, $516.1,633.4$ and $54.2 \mathrm{~kg} \mathrm{ha}^{-1}$, respectively. This species showed highest yield at 30\% FC moisture content which was not significantly different than at $50 \% \mathrm{FC}$ and lowest yield was under rain fed treatment. Eragrostis superba and Enteropogon macrostachyus did not have any significantly difference in yields across the three soil moisture content. However, they showed lower and significant different yield under rain fed treatment. Cenchrus ciliaris did not show any significant difference in yields across all the three soil moisture content levels and rain fed, but the yields under rainfall were lower. Chloris gayana showed the highest seed yield $\left(1066.8 \mathrm{~kg} \mathrm{ha}^{-1}\right)$ at $30 \% \mathrm{FC}$ soil moisture content compared to $80,50 \% \mathrm{FC}$ soil moisture content and rain fed having $766.9,866.8$ and $123.7 \mathrm{~kg} \mathrm{ha}^{-1}$, respectively. Sorghum sudanense (Sudan grass) showed the highest yield that was significantly different $(\mathrm{p} \leq 0.05)$ from rest five grass species at $80 \% \mathrm{FC}$ having $1250.7 \mathrm{~kg} \mathrm{ha}^{-1}$ and was also the highest yielder under rain fed condition $\left(150.7 \mathrm{~kg} \mathrm{ha}^{-1}\right)$. Generally, all the watered treatments produced higher seed yields than the rain fed treatment.

Table 1. Seed yields $\left(\mathrm{kg} \mathrm{ha}^{-1}\right)$ of six range grass species produced at $80,50,30 \% \mathrm{FC}$ soil moisture content and rain fed

\begin{tabular}{|c|c|c|c|c|}
\hline & $80 \% \mathrm{FC}$ & $50 \% \mathrm{FC}$ & $30 \% \mathrm{FC}$ & Rain fed (control) \\
\hline C R & $103.3^{\mathrm{a}} \pm 5.77$ & $516.1^{\mathrm{c}} \pm 7.64$ & $633.4^{\mathrm{c}} \pm 14.43$ & $54.2^{\mathrm{ab} \pm 9.62}$ \\
\hline E S & $350.1^{\mathrm{b}} \pm 57.66$ & $286.0^{\mathrm{b}} \pm 41.63$ & $343.2^{\mathrm{b}} \pm 50.57$ & $39.8^{\mathrm{a}} \pm 7.91$ \\
\hline EM & $566.3^{\mathrm{c}} \pm 2.88$ & $550.4^{\mathrm{c}} \pm 0.00$ & $516.3^{\mathrm{c}} \pm 5.77$ & $21.8^{\mathrm{a}} \pm 4.43$ \\
\hline CC & $150.5^{\mathrm{a}} \pm 13.22$ & $136.6^{\mathrm{a}} \pm 16.07$ & $156.6^{\mathrm{a}} \pm 20.21$ & $123.7^{\mathrm{c}} \pm 33.21$ \\
\hline CG & $766.9^{\mathrm{d}} \pm 15.27$ & $866.8^{\mathrm{d}} \pm 20.20$ & $1066.8^{\mathrm{e}} \pm 2.88$ & $150.7^{\mathrm{c}} \pm 31.42$ \\
\hline SB & $1250.7^{\mathrm{e}} \pm 7.07$ & $700.5^{\mathrm{d}} \pm 10.00$ & $533.9^{\mathrm{c}} \pm 2.88$ & \\
\hline
\end{tabular}

Means within the same columns with different superscripts are significantly different at $\mathrm{p} \leq 0.05$.

Key: $\mathrm{CR}=$ Chloris roxburghiana, $\mathrm{ES}=$ Eragrostis superba, $\mathrm{EM}=$ Enteropogon macrostachyus, $\mathrm{CC}=$ Cenchrus ciliaris, $\mathrm{CG}=$ Chloris gayana, $\mathrm{SB}=$ Sorghum sudanense

\pm Standard deviation 
Table 2. Mean number of productive tillers of six range grass species produced at $80,50,30 \% \mathrm{FC}$ soil moisture content and rain fed

\begin{tabular}{|c|c|c|c|c|}
\hline & $80 \% \mathrm{FC}$ & $50 \% \mathrm{FC}$ & $30 \% \mathrm{FC}$ & Rain fed (control) \\
\hline $\mathrm{C} \mathrm{R}$ & $11.1^{\mathrm{a}} \pm 2.3$ & $10.8^{\mathrm{ab}} \pm 3.3$ & $12.3^{\mathrm{ab}} \pm 6.3$ & $3.3^{\mathrm{ab}} \pm 1.3$ \\
\hline $\mathrm{E} \mathrm{S}$ & $19.3^{\mathrm{a}} \pm 4.7$ & $14.3^{\mathrm{ab}} \pm 5.8$ & $18.3^{\mathrm{b}} \pm 7.1$ & $3.1^{\mathrm{a}^{\mathrm{b}}} \pm 1.1$ \\
\hline $\mathrm{EM}$ & $16.2^{\mathrm{a}} \pm 2.3$ & $14.1^{\mathrm{ab}} \pm 3.3$ & $12.1^{\mathrm{ab}} \pm 2.4$ & $4.1^{\mathrm{b}} \pm 2.3$ \\
\hline $\mathrm{CC}$ & $28.0^{\mathrm{b}} \pm 6.4$ & $22.0^{\mathrm{b}} \pm 11.4$ & $20.0^{\mathrm{b}} \pm 8.4$ & $4.7^{\mathrm{b}} \pm 2.4$ \\
\hline $\mathrm{CG}$ & $21.1^{\mathrm{b}} \pm 11.1$ & $18.1^{\mathrm{ab}} \pm 9.1$ & $16.3^{\mathrm{b}} \pm 9.4$ & $4.3^{\mathrm{b}} \pm 1.2$ \\
\hline SB & $31.0^{\mathrm{b}} \pm 16.1$ & $29.0^{\mathrm{c}} \pm 6.1$ & $31.2^{\mathrm{c}} \pm 11.1$ & $5.2^{\mathrm{b}} \pm 2.1$ \\
\hline
\end{tabular}

Means within the same columns with different superscripts are significantly different at $\mathrm{p} \leq 0.05$.

$\mathrm{Key}$ : $\mathrm{CR}=$ Chloris roxburghiana, $\mathrm{ES}=$ Eragrostis superba, $\mathrm{EM}=$ Enteropogon macrostachyus, $\mathrm{CC}=$ Cenchrus ciliaris, $\mathrm{CG}=$ Chloris gayana, $\mathrm{SB}=$ Sorghum sudanense

\pm Standard deviation

Table 2 presents grass species reproductive tiller numbers during mature and ripened seed stage (week 12 from planting). The tiller numbers of the six grass species did not have significant difference for the 80,50 and $30 \%$ FC soil moisture content. However, there was a significant difference $(p \leq 0.05)$ in the tiller numbers under rain fed treatment compared to the three soil moisture content levels for all the grasses.

\section{Discussions}

The results suggest different grasses have varied seed productivity levels under varied soil moisture content. This may be attributed to the morphological characteristics of the specific grass species as determined by individual genetic composition and adaptability to different soil water conditions $[14,16]$. Sorghum sudanense has larger seed size than all the five grass species and hence observed higher yields compared to Cenchrus ciliaris and Enteropogon macrostachyus which have spikelet's measuring $<10 \mathrm{~mm}$ long. When Eragrostis superba and Cenchrus ciliaris were compared for seed yields in relation to size of spikelets, where the latter has higher spikelet densities per inflorescence thus higher seed yields. The findings concur with those of [18], who reported Eragrostis superba to have higher seed yield compared to Cenchrus ciliaris and attributed this to inherent morphological characteristics. The number of tillers with panicles per plant may also have contributed to the differences in seed yields. This was also reported by [4] working with Sorghum sudanense who found a positive correlation between grain yields and number of productive panicles per plant. It has been reported that grass plants with many reproductive tillers produce more seeds $[1$, 7,29 ] compared to species having fewer productive tillers or many but unproductive tillers. This was observed in Sorghum sudanense under this study showing higher number of productive tillers that contributed to higher seed yields compared to Cenchrus ciliaris and Enteropogon macrostachyus (Table 2). This observation was also observed by [25] working with Enteropogon Macrostachyus, Eragrostis superba and Cenchrus ciliaris under rain fed trials with different land preparation methods (reaped and hand cleared).

The observed higher tiller numbers for Sorghum sudanense at all the three soil moisture content and rain fed treatments may explain the observed higher seed yields for the species at $80,50 \% \mathrm{FC}$ and rainfed conditions. This finding concurs with those of [18], where tiller densities varied with range grass species and influenced biomass productivity. Besides tiller numbers influencing seed yields of grasses, they also influenced adaptability to grazing pressure, determining photosynthetic rates and as source of food reserves [11]. The number of tillers in a plant determines the biomass production and the quality of forage yield $[16,32]$. The tillers contain leaves which have more easily digestible nutrients and less structural components especially from the newly developed tillers with young leaves [38]. However, typically, a tiller will have both old leaves from previous growth season and young leaves. The old leaves are lower in quality but contribute to the total biomass yields [33], while the young ones bring in the balance to improve the quality.

The lower tiller numbers under rain fed treatment can be attributed to the grass plants water stress during the growing season which enhances response of leaf and tiller firing to reduce transpiration losses $[31,37]$. On the other hand, the observed increase in tiller numbers for watered treatments can be attributed to adequate water supply that reduced water stress and enhanced tiller recruitment. Water plays important role in nutrient absorption and translocation by plants as well as maintaining plant temperature through transpiration [23] which could have been a challenge for rain fed treatment under this study. These findings are contrary to those of [35] who working on Bothriochloa ischaemum grass under rainfall and rainfall plus $25 \mathrm{~mm} /$ week of supplementary irrigation reported soil moisture content to have no impact on tiller density.

Irrigation has been documented to not only increase the chances of successful establishment of grasses but also to have effects on subsequent seed yields for pastures $[8,12$, 34]. The observed low seed yields by the six grass species under rain fed conditions compared to the watered treatments can be attributed to water stress that limited the plants 
physiological process and hence low productivity of biomass that translated into low seed yields. [13] reported Sorghum sudanense to have seed yields of $130 \mathrm{~kg} \mathrm{ha}^{-1}$ and $110 \mathrm{~kg} \mathrm{ha}^{-1}$ under irrigation and rain fed production, respectively. This finding closely mirrors our study findings showing rainfed treatment having lower seed yields than irrigated conditions. [9] working with perennial ryegrass, white clover, and tall fescue (Festuca arundinacea Schreb.) also observed the leaf DM to be lower under water stress plants than in irrigated plants by the end of the drought.

\section{Conclusions}

This study reveals that watering of grass species increases seed yields and different grass species have different responses to varied soil moisture content. Chloris gayana has demonstrated to have greater potential of producing higher quantities of seeds at low watering levels having more than $1 \mathrm{t} \mathrm{ha}{ }^{-1}$. Eragrostis superba and Enteropogon macrostachyus had no significant difference in seed yields at different soil moisture content levels. Chloris roxburghiana having higher seed yields at medium irrigation level and reduced yields at higher and at lower moisture levels. Sorghum sudanense showed highest seed yields at higher soil moisture content of $80 \% \mathrm{FC}$ compared to the five grasses and was still the highest seed yielder under rain fed treatment. These findings are very handy for farmers who are doing pasture seed multiplication and give a means of making guided decisions on agronomic practices for seed production. Sorghum sudanense, Enteropogon macrostachyus and Chloris gayana showed better performance for biomass production even at lower moisture levels and also better seed production at lower moisture levels puts them at a strategic point as farmer's choice where moisture deficit is more pronounced. Also, Cenchrus ciliaris showed potential for seed production even under moisture deficits under this study (rain fed) by having no significant difference with the watered treatments in terms of seed yields. We, therefore, recommend that range grass irrigation increases grass seed yields for all the species tested compared to water deficit observed under rainfed with Sorghum sudanense and Chloris gayana performing better at watered and rainfed conditions.

\section{Acknowledgements}

This work was jointly supported by National Irrigation Board (NIB) Kenya, National Council of Science, Technology and Innovation (NCSTI), German Academic Exchange Service (DAAD)-Kenya and the Center for Sustainable dryland ecosystems and societies, (CSDES)-University of Nairobi, Kenya.

\section{REFERENCES}

[1] Adler, P. R., Sanderson, M. A., Boateng, A. A., Weimer, P. J., \& Jung, H. J. G. (2006). Biomass yield and biofuel quality of switchgrass harvested in fall or spring. Agronomy Journal, 98(6), 1518-1525.

[2] Allen, V. G., Baker, M. T., Segarra, E., \& Brown, C. P. (2007). Integrated irrigated crop-livestock systems in dry climates. Agronomy Journal, 99(2), 346-360.

[3] Anderson, V., \& Schatz, B. (2003). Biological and economic synergies, and methods of integrating beef cow and field crops enterprises. 2002. http://www.ag.ndsu.edu/pubs/ansci/ beef/2002beef.pdf\#page=3. Accessed 25th Feb 2013

[4] Awad, A., Salah H., Mohammed, S. H., Azza, E., Salah, E. (2013). Grain yield production of Sudan grass (Sorghum sudanense (Piper) Stapf) as influenced by cutting numbers, potassium rates, and intrarow spacing in a semiarid environment. Turkish Journal of Agriculture and Forestry (2013) 37

[5] Clay, D. E., Clay, S. A., Reitsma, K. D., Dunn, B. H., Smart, A. J., Carlson, G. G., \& Stone, J. J. (2014). Does the conversion of grasslands to row crop production in semi-arid areas threaten global food supplies? Global Food Security. http://www.sciencedirect.com/science/article/pii/S22119124 13000564. Accessed 25th Feb 2013

[6] Griffiths, R. (1993). Sustainable supplies of quality herbage seed for sub-Saharan Africa smallholder's pp. 662-665. In: MJ Baker (ed). Grasslands for our world. Sir Publishing, Wellington, New Zealand

[7] Guan, D., Al-Kaisi, M. M., Zhang, Y., Duan, L., Tan, W., Zhang, M., \& Li, Z. (2014). Tillage practices affect biomass and grain yield through regulating root growth, root-bleeding sap and nutrients uptake in summer maize. Field Crops Research, 157, 89-97.

[8] Horton H., Asay K. H., Glover T. F., Young S. A., Haws B. A., Dewey S. A. \& Evans J. O. (1990). Grass Seed Production for Guide for Utah. ttp://tinyurl.com/qbs8pxq. Accessed 27th Feb 2013

[9] Karsten, H. D., \& MacAdam, J. W. (2001). Effect of drought on growth, carbohydrates, and soil water use by perennial ryegrass, tall fescue, and white clover. Crop Science, 41(1), 156-166.

[10] Kigomo, J. N. \& Muturi G. M. (2013). Impacts of enclosures in rehabilitation of degraded rangelands of Turkana County, Kenya. Journal of Ecology and the Natural Environment. Vol. 5(7), pp. 165 171. http://www.academicjournals.org/jene/PD F/Pdf2013/July/Kigomo\%20and\%20Muturi.pdf

[11] Laidlaw, A.S. (2005). The relationship between tiller appearance in spring and contribution of dry matter yield in perennial ryegrass (Lolium perenne L.) cultivars differing in heading date. Grass and Forage Science, 60:200-209

[12] Lee, J. M., Clark, A. J., \& Roche, J. R. (2013). Climate change effects and adaptation options for temperate pasture - based dairy farming systems: a review. Grass and Forage Science, 68(4), 485-503

[13] Martiniello, P., Gesualdo, G., Sabia, E., Terzano, M. G, Pacelli, C. \& Berardo, N. (2007). Intensive rainfed and irrigated forage crop production for Mediterranean Italian 
buffalo feeding. Italian Journal of Animal Science 6, 1226-1229.

[14] Masuka, B., Araus, J. L., Das, B., Sonder, K., \& Cairns, J. E. (2012). Phenotyping for Abiotic Stress Tolerance in MaizeF. Journal of integrative plant biology, 54(4), 238-249.

[15] Mganga, K. Z., Musimba, N. K. R., Nyangito, M. M., Nyariki, D. M., \& Mwang'ombe, A. W. (2010c). Improving Hydrological Responses of Degraded Soils in Semi Arid Kenya. Journal of Environmental Science \& Technology, 3(4). 217-225.

[16] Mganga, K. Z., Musimba, N. K. R., Nyariki, D. M., Nyangito, M. M., \& Mwang'ombe, A. W. (2013). The choice of grass species to combat desertification in semi - arid Kenyan rangelands is greatly influenced by their forage value for livestock. Grass and Forage Science. http://onlinelibrary.wiley.com/doi/10.1111/gfs.12089/full. Accessed 20th Feb 2014

[17] Mganga, K. Z., Musimba, N. K., Nyangito, M. M., Nyariki, D. M., Mwangombe, A. W., Ekaya, W. N., \& Verhagen, J. (2010a). The role of moisture in the successful rehabilitation of denuded patches of a semi-arid environment in Kenya. Journal of Environmental Science and Technology, 3, 195-207.

[18] Mganga, K. Z., Musimba, N. K., Nyariki, D. M., Nyangito, M. M., Mwang'ombe, A. W., Ekaya, W. N., and Muiru, W. M. (2010b). Dry matter yields and hydrological properties of three perennial grasses of a semi-arid environment in east Africa. African Journal of Plant Science, 4(5), 138-144.

[19] Mnene, W.N. (2005). Strategies to increase success rates in natural pasture development through reseeding degraded rangelands of Kenya. PhD Thesis, University of Nairobi, Nairobi, Nairobi, Kenya

[20] Musimba, N.K.R., Nyariki D.M., Ikutwa C.N. \& Teka T. (2004). Dryland Husbandry for sustainable development in the southern rangelands of Kenya. OSSREA, Addis Ababa, 2004.

[21] Nyangito, M.M. (2005). Grazing patterns, energy extraction and livestock productivity in agropastoral production systems in Kibwezi, southeastern Kenya. PhD Thesis, University of Nairobi, Nairobi, Kenya.

[22] Nyangito, M.M. Musimba, N.K.R \& Nyariki D.M. (2008). Range use and dynamics in the agropastoral system of southeastern Kenya. African Journal of Environmental Science and Technology 2(8): 220-230

[23] Oddo, E., Inzerillo, S., Grisafi, F., Sajeva, M., Salleo, S., \& Nardini, A. (2014). Does short-term potassium fertilization improve recovery from drought stress in laurel? Tree Physiology, tpt120

[24] Ogillo, B. P., Nyangito, M. M., Nyariki, D. M., \& Kubasu, D. O. (2010): A comparison of two micro-catchment technologies on aboveground biomass production and financial returns of three range grasses in southern Kenya, pp 849 - 854. http://tinyurl.com/orrvglq. (Accessed 15th May 2012)
[25] Opiyo, F. E., Ekaya, W. N., Nyariki, D. M., \& Mureithi, S. (2011). Seedbed preparation influence on morphometric characteristics of perennial grasses of a semi-arid rangeland in Kenya. African Journal of Plant Science, 5(8), 460-468.

[26] Opiyo, F.O. (2007). Land treatment effects on morphometric characteristics of three grass species and economic returns from reseeding in Kitui district, Kenya. MSc Thesis, University of Nairobi, Nairobi, Kenya.

[27] Reynolds, S. G., Batello, C., Baas, S., \& Mack, S. (2005). Grassland and forage to improve livelihoods and reduce poverty. Grassland: A global resource. Wageningen Academic Publishers, Wageningen, the Netherlands, 323-338.

[28] SAS Institute. (2011). SAS 9. 3 Output Delivery System: User's Guide. SAS institute.

[29] Silvertown, J., \& Charlesworth, D. (2009). Introduction to plant population biology. Wiley. com. http://tinyurl.com/o4oyddd. Accessed 12th Jan 2014.

[30] Simba, F. M., Mubvuma, M., Murwendo, T., \& Chikodzi, D. (2013). Prediction of yield and biomass productions: A remedy to climate change in semi-arid regions of Zimbabwe. International Journal of Advance Agricultural Research, 1, 14-21.

[31] Singer, J. W. (2002). Species and nitrogen effect on growth rate, tiller density, and botanical composition in grass hay production. Crop science, 42(1), 208-214.

[32] Skinner H.R., \& Moore K.J. (2007). Growth and development of forage plant. In: Barnes R.F., Nelson C.J., Moore K.J.,Collins M. (eds): Forages: The Science of Grassland Agriculture. 6th Ed. Wiley-Blackwell, Ames, USA, 53-66.

[33] Soininen E. M., Hübner C. E. \& Jónsdóttir I. S. (2010). Food selection by barnacle geese (Branta leucopsis) in an Arctic pre-breeding area. Polar Research. 29: 404-412

[34] Sulc, R. M., \& Franzluebbers, A. J. (2013). Exploring integrated crop-livestock systems in different ecoregions of the United States. European Journal of Agronomy. http://www.sciencedirect.com/science/article/pii/S11610301 13001482. Accessed 3rd Jan 2014

[35] Teague, W.R. \& Dowhower, S.L. (2002). Irrigation impact on harvest efficiency in grazed Old World Bluestem. Journal of Range Manage. 55: 260-265 May 2002

[36] USAID, (2011). Drylands Livestock Development Program. http://kenya.usaid.gov/programs/economic-growth/412 (Accessed 26th September, 2013)

[37] Volaire, F., Norton, M. R., \& Lelièvre, F. (2009). Summer drought survival strategies and sustainability of perennial temperate forage grasses in Mediterranean areas. Crop Science, 49(6), 2386-2392

[38] Wilson J.R., Deinum B., \& Engels F.M. (1991). Temperature effects on anatomy and digestibility of leaf and stem of tropical and temperate forage species. Netherlands Journal of Agricultural Science, 39, 31-48. 